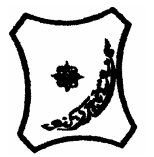

Bayero Journal of Pure and Applied Sciences, 9(2): 263 - 266

Received: June, 2015

Accepted: April, 2016

ISSN $2006-6996$

\title{
EFFECT OF WEEDING STATUS AND TAPPING DATE ON THE YIELD OF GUM ARABIC (ACACIA SENEGAL) IN JIGAWA STATE, NIGERIA
}

\author{
Ilu, K. J. ${ }^{1}$, Yau I. A. ${ }^{1}$, Babura M.S ${ }^{1}$, Zahran, Bashir B. H. ${ }^{2}$, Sid Ahmed, Abdulsalam, $0^{2}$. and Ahmed, \\ $H^{1}$ \\ ${ }^{1}$ Binyaminu Usman Polytechnic, PMB 013, Hadejia, Jigawa State, Nigeria. \\ ${ }^{2}$ Department of Forestry and Pasture Sciences, Faculty of Agriculture\& Natural Resources, University of Bakht \\ Alruda, dueim, Sudan. \\ Corresponding author: ilukawuwa@yahoo.com, +2348138300491
}

\begin{abstract}
The study examined the Effect of Weeding Status and Tapping Date on the yield of gum Arabic (Acacia senegal) in Jigawa State, Nigeria. The said task has been accomplished by employing a two factorial experiment of complete randomized block design with three replicates which involves the weeding status and tapping dates conducted in 2014 season at two different locations; Kadoma and Kwanar duhuwa. The weeding status experiment comprises of three $100 \%$ weeded plots; and three Unwweded plots; while the tapping date investigation was tested at six levels $\left(1^{\text {st }}\right.$ and $15^{\text {th }}$ September, $1^{\text {st }}$ and $5^{\text {th }}$ October and $1^{\text {st }}$ and $15^{\text {th }}$ November). In each of these treatments three (3) trees were tapped making a total number of two hundred and sixteen trees in the two locations and one hundred and eight (108) trees at kadoma and Kwanar duhuwa respectively.

The first picking of the gum yield took place 45day after tapping and each consecutive picking was collected after 15 days from the previous one. The gum from each picking was weighed after air drying with sensitive balance JY2002 model. SAS statistical package used for the data analysis thus DUNCAN multiple range test were employed in establishing the relationships between the variable investigated.Thus, the finding has revealed that gum Arabic tapping conducted on the $15^{\text {th }}$ of October gave higher yield of gum Arabic when compared with the rest dates of tapping; the unweeded plots gave superior yield than the weeded plot.Therefore gum Arabic farmers were advised not to weed gum Arabic field when they are matured enough for harvest at the same time tapping should be carried out when the gum Arabic tree lost at least $50 \%$ of their leaves.
\end{abstract}

Keywords; Gum Arabic, Jigawa State, Tapping and Weeding.

INTRODUCTION

FAO (1992), defines gumArabic as the "dried exudation obtained from the stems and branches of Acacia senegal L. (Wild) or closely related species. Acacia senegal L.(Wild) is an economic tree plant which produces the exudates called gum Arabic. This important plant is naturally well adapted to the semiarid zones of Sudan and Sahel regions (Odo, 2003). People use gums for a variety of purposes as adhesive; for clarification liqueurs; finishing of silk; preparation of quality water colors; in pharmaceuticals, printing inks and the sizing and finishing of textile fabrics and dyeing in paint industry, in cosmetics to bind creams, lotions and ointments; in preparation of ice cream, chewing gum and other confectionaries items and in soft drink manufacture (Grams, 1998). Gum Arabic is the second export commodity and hard currency earner, in this respect, Sudan commands over $80 \%$ of the World's gum Arabic production and trade. Besides its significant economic role for the country, gum Arabic plays an important role in rural life, providing steady income to rural families especially in years when productions of crops fail (Chikemi, et al., 1997). Nair et al., (1995) added, millions of people worldwide, especially in developing countries depend on collection of gums, resins and latex as a means for their livelihood. Bready (2009)describedweed as a plant considered undesirable in a particular situation, "a plant in the wrong place". Examples commonly are plants unwanted in human-controlled settings, such as farm fields, gardens, lawns, and parks. Taxonomically, the term is also applied to any plant that grows or reproduces aggressively, or is invasive outside its native habitat the term "weed" has no botanical significance, because a plant that is a weed in one context is not a weed when growing in a situation where it is in fact wanted.

Tapping is a traditional way of producing gum in Sudan (Kamal and Adam, 2011). Wekesa, et al (2012) stated that untapped trees did not produce at all/produced little gum implying that tapping is an important management tool for enhancing gum productivity. The best time to tap a tree for high output is about 9 a.m. in the morning and 5 p.m. in the evening (Odo, 1994).Ballal (1991) stated that "gum yield varies greatly with differences in husbandry practices namely the time and intensity of tapping and tapping methods. Forest products may be consumed locally or exported as raw materials to other countries where they are needed (FAO, 1992). Realization of this fact, the Government of Northern Nigeria coupled with the Forest II project supported by World Bank in 1987 mounted campaigns which promoted the planting of Acacia senegal and resulting in many farmers establishing large farms of Acacia senegal (Aghughu et al, 1996). 
Unfortunately there wasn't any research conducted on the management practices, the precise technique and time of tapping gum Arabic trees for optimum gum yield particularly in Jigawa State. Therefore this research is intended to assist farmers in overcoming thus hitches in order to enable them enjoy, the full benefits of their investments.

\section{The Study Area}

Jigawa state was excised from Kano State in 1991, covers a total land area of about22, $410 \mathrm{Km}^{2}$ (CBUDP, 2007). Currently the population of the State was estimated to be $4,361,002$ (NBS, 2006). It is situated in the north-western part of Nigeria and lies between latitudes $11^{\circ} 14^{1} \mathrm{~N}$ and $13^{\circ} 09^{1} \mathrm{~N}$ and between longitudes $8^{\circ} 00^{1} \mathrm{E}$ to $10^{\circ} 15^{1} \mathrm{E}$ (Mikaill, 2001). It has a unique climate with relatively rapid changes in temperature and humidity (Mikail, 2001). The temperature may rise to $33^{\circ} \mathrm{C}$ during the summer months, usually in April and May and could be as low as $21^{\circ} \mathrm{C}$ during winter period (December/January). Rainfall varies from year to year and ranges from $635.00 \mathrm{~mm}$ in the north to $890.0 \mathrm{~mm}$ in the Southern area (NEST, 1991).

\section{Description of the Study site}

The first location of the field experimentation was Kwanar Duhuwa a village six (6) kilometers away from Gumel town. The plantation which covers up to 83.26 hectare was established in the year 2004 at a $4 \times 4$ metres spacing distances. (Latitude $12^{\circ} 34^{1} \mathrm{~N}$, Longitude $09^{\circ} 24^{1} \mathrm{E}$ ) it is placed at an Altitude of $374 \mathrm{~m}$. The soil is loamy sand while the mean annual rainfall varies from $336.8 \mathrm{~mm}$ to $576.5 \mathrm{~mm}$. The second location was Kadoma village located almost three (3) kilometres away from Jahun town, the plantation which covers 20.63 hectares was established in 2003 that is a year ahead of the former plantation, at spacing distances of $4 \times 4$ metres also. (Latitude $12^{\circ} 06^{1} \mathrm{~N}$ and Longitude $09^{\circ} 39^{1} \mathrm{E}$ ) it is placed at an Altitude of $372 \mathrm{~m}$. the soil is loamy sand and clay, the mean annual rainfall varies from $250.7 \mathrm{~mm}$ to $1001.1 \mathrm{~mm}$ that extended from April to September, the average wind velocity reached $5.48 \mathrm{~km} / \mathrm{hr}$, the atmospheric humidity reached $19.1 \%$ in January and $66.8 \%$ in August and the Minimum and Maximum temperature were $17.57^{\circ} \mathrm{C}$ and $37.13^{\circ} \mathrm{C}$ respectively (JSSYB, 2008).

\section{Experimental Design}

The experiment was conducted at two locations; Kadoma and Kwanar duhuwa in2014 season which involved two factorial of complete randomize block design with three replicates. The first factor consisted of weeding status, where three randomly located plots of $30 \mathrm{~m} \times 30 \mathrm{~m}$ were $100 \%$ weeded. Equal number of plots were left Unweededat each of the two sites, while the second factor comprises date tapping tested at six levels ( $1^{\text {st }}$ and $15^{\text {th }}$ September, $1^{\text {st }}$ and $5^{\text {th }}$ October and $1^{\text {st }}$ and $15^{\text {th }}$ November).

\section{Tapping}

Tapping of Acacia senegal (gum Arabic tree) was done by using the developed new hand tool called (Sinki) (Elamin, 1989).The Sonki is driven under the bark of the tree without penetrating the wood between the outer bark and inner cambium (IIED and
IES, 1989).Three (3) trees were tapped at each plot making a total number of hundred and eight (108) trees used in each location, which stood at (216) two hundred and sixteen trees tapped in the two locations. The first gum picking of the dry gum exudates took place 45 days after tapping and each consecutive picking was collected after 15 days from harvest of previous one.The gum from each picking was weighed after drying using sensitive balance JY2002 model. Average gum yields per tree were computed and used in the analysis using SAS system where DUNCAN's Multiple Range Test was used in determining the significance of weeding status and date of tapping for the separate locationon the total yield.

\section{RESULTS AND DISCUSSION}

The gum production potential of this species (Acacia senegal) is still untapped in most of the areas because of unproductive and interest less effort in gum tapping. The gum producers are adopting traditional method of gum tapping, in which tree is wounded at various parts, which is laborious and causes more injuries to the tree and in turn, the tree produces a very low quantity of gum due to which gum tappers have no interests in gum tapping (Moola, 2003). Though some gum will flow naturally from cracks in the bark of the Acacia senegal tree, commercial tappers stimulate the flow by removing thin strips of bark, an operation that requires some skill if the tree is not to be injured.

The findings has shown that tapping date had profound effect on the yield of gum Arabic in that gum yields of $155 \mathrm{~g} /$ tree and $159.72 \mathrm{~g} /$ tree were obtained when the trees were tapped on the $15^{\text {th }}$ October, as against $7.67 \mathrm{~g} /$ tree and $5.84 \mathrm{~g} /$ tree when they were tapped on the $1^{\text {st }}$ September, gum yields of $89.09 \mathrm{~g} /$ tree and $75.35 \mathrm{~g} /$ tree were achieved when the trees were tapped on the $15^{\text {th }}$ November at Kadoma and Kwanar duhuwa sites respectively figure (1 and 2 ). Therefore the gross variations on the gum yield noticed of $15^{\text {th }}$ October tapping was as a result of the stoppage of rainfall three weeks to the commencement of tapping and the shedding of fifty percent $(50 \%)$ of the gum Arabic tree leaves which could be the motivating factor towards the exudation of more gum when the trees were tapped on the $15^{\text {th }}$ October. The findings of this study is in line with the findings of Kamal and Adam (2011) who found, the $15^{\text {th }}$ October date of tapping show slight increase in gum yield. This result also agreed with the findings of Fadl and Gebauer (2006) they investigated the effect of date of tapping and tapping intensity on the gum yield of $A$. seyal and found that the date of tapping had significant effect on the amount gum production. The investigation has revealed that weeding had negative impact on the yield of gum Arabic, as in figure ( 3 and 4 ) higher gum Arabic yields of $(90.62 \mathrm{~g}$ and $76.18 \mathrm{~g}$ ) were obtained at the un weeded plot, in comparison with the low gum yields of $(58.16 \mathrm{~g}$ and $65.48 \mathrm{~g}$ ) realized at the $100 \%$ weeded sites of both Kadoma and Kwanar duhuwa respectively. However Kamal et al (2013) observed significant effect of grass density on Acacia senega/gum in some pickings. 
The plant is only susceptible to weeds attack at seedling stage but a necessary factor (weeds stress) for optimum gum production at maturity (Bada and Unanaonwi, 2013). Thus, Ewel (1999) states the accumulation of litter can affect plant community composition by affecting the temperatures, nutrient availability and light availability of the soil environment, thereby forming a potentially important linkage between recent productivity and current ecosystem processes. The herbaceous vegetation associated with gum Arabic tree varies considerably throughout the gum belt (International Institute of Environmental Studies, IIED and IES, 1989). On the other hand, there is a strong belief that presence of grasses around trees increases gum Arabic yield, the more the grasses exist, the more gum yield expected. The invasion of grasses might render gum Arabic trees under stress, hence, Nair et al (1995) state, Poor soil; drought and other hostile environmental conditions promote gum Arabic production.

Table 1: Average gum Arabic yield (g/picking) as affected by tapping date in 2014 season at Kadoma plantation

\begin{tabular}{|c|c|c|c|c|c|c|c|}
\hline \multirow[t]{2}{*}{ Dates } & \multicolumn{5}{|c|}{ Gum Arabic yield g/picking } & \multirow{2}{*}{$\begin{array}{l}\text { Total } \\
\text { Yield }\end{array}$} & \multirow{2}{*}{$\begin{array}{l}\text { Average } \\
\text { yield }\end{array}$} \\
\hline & $1^{\text {st }}$ picking & $2^{\text {nd }}$ picking & $3^{\text {rd }}$ picking & $4^{\text {th }}$ picking & $5^{\text {th }}$ picking & & \\
\hline $1^{\text {st }}$ Sept. & $0.10 c$ & $0.10 \mathrm{c}$ & $1.10 \mathrm{c}$ & $3.22 \mathrm{~d}$ & $3.15 c$ & 7.67 & 1.53 \\
\hline $15^{\text {th }}$ Sept & $0.00 \mathrm{c}$ & $0.83 c$ & $0.83 c$ & $2.00 \mathrm{~d}$ & $2.50 c$ & 6.16 & 1.25 \\
\hline $1^{\text {st }}$ Oct. & $12.18 \mathrm{~b}$ & $16.40 \mathrm{~b}$ & $21.18 \mathrm{~b}$ & $24.50 \mathrm{~b}$ & $25.68 \mathrm{ab}$ & 99.94 & 19.99 \\
\hline $15^{\text {th }}$ Oct & $18.65 a$ & $26.42 \mathrm{a}$ & $37.18 \mathrm{a}$ & $37.90 \mathrm{a}$ & $34.85 \mathrm{a}$ & 155.00 & 31 \\
\hline $1^{\text {st }}$ Nov. & $11.4 \mathrm{~b}$ & $16.83 b$ & $21.08 b$ & $20.93 b c$ & $18.85 b$ & 78.09 & 15.62 \\
\hline $15^{\text {th }}$ Nov. & $10.43 \mathrm{~b}$ & $15.83 \mathrm{~b}$ & $18.08 \mathrm{~b}$ & $20.60 c$ & $23.75 b$ & 89.09 & 17.82 \\
\hline Means & 878 & 12.72 & 16.57 & 18.19 & 18.13 & & \\
\hline SE \pm & $1 . .68$ & 1.87 & 2.11 & 2.05 & 5.29 & & \\
\hline
\end{tabular}

${ }^{*}$ Treatment means followed by the same letters in the same columns are not significantly Different at $p<0.005$

Table 2: Average gum Arabic yield of (g/picking) as affected by tapping date in2014 at Kwanar dahuwa plantation

Dates Gum Arabic yield gram/picking

Total yield Average

yield

\begin{tabular}{lcccccrc}
\multicolumn{1}{c}{} & $1^{\text {st }}$ picking & $2^{\text {nd }}$ picking & $3^{\text {rd }}$ picking & $4^{\text {th }}$ picking & $5^{\text {th }}$ picking & & \\
\hline $1^{\text {st }}$ Sept. & $0.33 \mathrm{~d}$ & $0.00 \mathrm{~d}$ & $0.00 \mathrm{~d}$ & $208 \mathrm{~d}$ & $3.43 \mathrm{c}$ & 5.84 & 1.17 \\
$15^{\text {th }}$ Sept & $0.00 \mathrm{~d}$ & $0.83 \mathrm{~d}$ & $2.25 \mathrm{~d}$ & $3.18 \mathrm{~d}$ & $4.50 \mathrm{c}$ & 10.76 & 2.15 \\
$1^{\text {st }}$ Oct. & $10.83 \mathrm{c}$ & $14.35 \mathrm{c}$ & $16.75 \mathrm{~b}$ & $15.48 \mathrm{c}$ & $22.15 \mathrm{ab}$ & 79.56 & 15.92 \\
$15^{\text {th }}$ Oct & $20.93 \mathrm{a}$ & $28.18 \mathrm{a}$ & $38.75 \mathrm{a}$ & $40.83 \mathrm{a}$ & $31.03 \mathrm{a}$ & 159.72 & 31.94 \\
$1^{\text {st }}$ Nov. & $12.25 \mathrm{~b}$ & $18.00 \mathrm{~b}$ & $19.00 \mathrm{~b}$ & $22.53 \mathrm{~b}$ & $19.00 \mathrm{~b}$ & 90.78 & 18.16 \\
$15^{\text {th }}$ Nov. & $11.85 \mathrm{c}$ & $14.00 \mathrm{c}$ & $16.00 \mathrm{bc}$ & $17.65 \mathrm{c}$ & $15.85 \mathrm{~b}$ & 75.35 & 15.07 \\
\hline Means & 9.86 & 12.56 & 15.46 & 16.95 & 15.99 & & \\
SE \pm & 1.30 & 1.26 & 1.44 & 2.28 & 6.04 & & \\
\hline
\end{tabular}

${ }^{*}$ Treatment means followed by the same letters in the same columns are not significantly different at $p<0.005$

Table 3: Effect of weeding status on average gum Arabic yield (g/picking) at Kadoma plantation Weeding Gum Arabic yield gram/picking status

$\begin{array}{ll}\text { Total } & \text { Average } \\ \text { yield } & \text { yield }\end{array}$

\begin{tabular}{|c|c|c|c|c|c|c|c|}
\hline & $1^{\text {st }}$ picking & $2^{\text {nd }}$ picking & $3^{\text {rd }}$ picking & $4^{\text {th }}$ picking & $5^{\text {th }}$ picking & & \\
\hline Weeded & $5.69 b$ & $9.28 b$ & $12.68 \mathrm{~b}$ & $14.18 b$ & $16.33 a$ & 58.16 & 11.63 \\
\hline Unweeded & $11.86 \mathrm{a}$ & $16.16 \mathrm{a}$ & $20.47 a$ & $22.20 \mathrm{a}$ & $19.93 a$ & 90.62 & 18.12 \\
\hline Total & 17,55 & 25.44 & 33.15 & 36.38 & 36.26 & 148.78 & 29.76 \\
\hline
\end{tabular}

*Treatment means followed by the same letters in the same columns are not significantly different at $p<0.005$

Table 4: Effect of weeding status on average gum Arabic yield (g/picking) at Kwanar duhuwa plantation

\begin{tabular}{|c|c|c|c|c|c|c|c|}
\hline \multirow{2}{*}{$\begin{array}{l}\text { Weeding } \\
\text { regime }\end{array}$} & \multicolumn{5}{|c|}{ Gum Arabic yield gram/picking } & \multirow{2}{*}{$\begin{array}{l}\text { Total } \\
\text { Yield }\end{array}$} & \multirow{2}{*}{$\begin{array}{l}\text { Average } \\
\text { yield }\end{array}$} \\
\hline & $1^{\text {st }}$ picking & $2^{\text {nd }}$ picking & $3^{\text {rd picking }}$ & $4^{\text {th }}$ picking & $5^{\text {th }}$ picking & & \\
\hline Weeded & $7.38 \mathrm{~b}$ & $9.84 b$ & $13.78 b$ & $16.92 a$ & $17.56 a$ & 65.48 & 13.10 \\
\hline Unweeded & $12.34 a$ & $15.28 \mathrm{a}$ & $17.14 a$ & $16.99 a$ & $14.43 a$ & 76.18 & 15.24 \\
\hline Total & 19.72 & 25.12 & 30.92 & 33.91 & 31.99 & 141.66 & 28.33 \\
\hline
\end{tabular}

${ }^{*}$ Treatment means followed by the same letters in the same columns are not significantly different at $p<0.001$ 


\section{CONCLUSION}

The results of the finding has revealed that gum Arabic tapping of the $15^{\text {th }}$ October gave higher yield moreover gum Arabic yields of the unweeded plots were greater than that of the weeded plots.

\section{RECOMMENDATION}

Gum Arabic farmers should tap Acacia senegal for maximum yield when the tree shed at least $50 \%$ of its leaves or three weeks after the stoppage of rainy season more over Acacia senegal require grass tress for optimum gum Arabic yield.

\section{Contribution of authors}

Ilu K. J., Zahran Bashir B. H., and A. O. Sid Ahmed contributed in the project design and manuscript

\section{REFERENCES}

Aghughu O, Ojiekpon I.F., and Alabi S.O. (1996, April). Origin of Acacia Senegal (L) Willd) and its distribution in Nigeria. A paper presented at the 31st Annual Conference of the Agricultural Society of Nigeria (ASN), Held at the National Agricultural Extension Research and Liaison Services (NAERLS), Ahmadu Bello University, Samaru - Zaria

Bada S.O. and Unanaonwi O. E. (2013). Effect of Tree Height and Girth on Gum Yield of Acacia senegal in Savannah Woodland of Nigeria. Journal of Tropical Forestry and Environment. $3(01), 40-44$.

Ballal, M. E. (1991). Acacia senegal:Multipurpose tree for the arid and semi-arid Tropics. M Sc. Thesis, University of wales, UK.

Bready, Richard S. "Dictionary." Microsoft $®$ Encarta $®$ (2009) [DVD]. Redmond, WA: Microsoft Corporation, 2008.

Chikemi, B. N., Casadei, E.,Coffen, J. J. W., Abdel Abur, H. O., and Cesareo, D. (1997). A Review of production, marketing and quality control of gum Arabic in Africa.

CBUDP (2007). Community Based Urban Development Project (2007): Pamphlet. Jigawa, Nigeria.

El amin H. M. A.(1989, March). The Consequences of Defoliation of Gum Arabic Tree (Acacia senegal) by Sahelian Tree Locust (Anacridium melanorhodon melanorhodon) for the Gum Producers in North Kordofan State, Sudan. Conference on International Research on Food Security, Natural Resources Management and Rural Development. Tropentag, 1989.

Ewel, S.(1999). Biology of plant. (7thed.) Harlow. England Pearson/Prentice Hall.

Fadi K. E.M and Gebauer J. 2006.Effect of time and intensity of tapping on the gum yielg of Acacia seyalvar seyal in South Kordofan, Sudan. Journal of Forests, Trees and livelihood, 16(3), 219-225

FAO. (1992). Gum Arabic (published in FAO Food and Nutrition paper (110) pp.735. $\mathrm{Http} / /$ www.codexalimentarius.net/gsfaomline/fo od/details.htm? id 230 FAO. Quality control of gum arabic in Nigeria Project TCP/ RAF/4557 Document. 1995.

Grams, J. (1998). Women's role in the International market for gum; summary of findings. Unpublished Report. New York: UNIFEM. writing while Yau I. and $\mathrm{H}$. Ahmed participated in the manuscript writing.

\section{Conflict of interest}

There wasn't any conflict of interest in the production of this manuscript both authors had common opinion on the work.

\section{Acknowledgement}

The authors have acknowledge the corporation rendered by Jigawa State Ministry of Environment for the release of important information and the owners of the plantation where the field experiment has been conducted Ahmad Mahmood Gumel and Mustapha Aminu (Wamban Duste).

JSSYB. ( 2008). Jigawa State Statistical year Book Pp 23. Jigawa State Government of Nigeria

IIED and IES. (1989). Gum Arabic rehabilitation in the republic of Sudan: Stage 1

Report, International Institute for Environment and Development (IIED) and Institute of Environmental Studies (IES). IIED. London.

Kamal E.M. and Adam I. M. (2011). Effect of tapping tools and date of tapping on Acacia polyacantha gum yield in south Kordofan State, Sudan. Journal of Forestry Research 22(1), 117-122.

Kamal, E.M., Ballal E. M., and Adam I. M.(2013). Effect of grass density and date of tapping on Acacia senegal gum yield in south Kordofan State, Sudan. Journal of forestry Research 24(1), 109172.

Mikail, B. A. (2001): "Deforestation and Afforestation Policy aimed at Sustaining the Land Resources Management in Jigawa State". Journal of Forestry, 2(1), 77-82.

Moola Ram, H., Khan, A., and Naveen, S. (2003).Tree Gum Tapping Technique of CAZRI Proved to be a Boon of Livelihood for Gum Arabic Tappers of Western Rajasthan in India. Central Arid Zone Research Institute, Jodhpur-34-2003, Rajasthan, India

Nair, M. N. B., Shivanna K. R. and Mohan H.Y. R.(1995). Ethephon enhances karaya gum yield and wound healing response: Food Hydrocolloids, 19 (4), 687-701, ISSN: 0268-005X

NIGERIA ENVIRONMENTAL STUDY/ACTION TEAM (1991): Nigeria's Threatened Environment $A$ National Profile .Pp 131-175.

NBS2006. National Bureau of Statistic (2006): Core Indicators Questionnaire Survey Reports on Jigawa. Abuja, Nigeria.

Odo, P. E.(2003, January, 14).Technics for Raising Seedlings in the Arid zone of Nigeria. Bulletin, No. 3 of Afforestation Programme Coordinating Unit [APCU] Kano.

Odo, P. E. (1994): "Tapping Gum Arabic plant: Practical Aspect". National Agricultural Extension and Research liaison service (NAERLS) Training Manual on gum Arabic production Pp. 20-23.

Wekesa, C J., Lelon,M., Muga, A., Luvanda E., and Chikamai, B.(2012). Gum Arabic production potential of natural Acacia senega/ varieties in drylands- kenya. handbook. DFID Forestry Research Programme, U.K. 